\title{
An Inclusive Organizational Climate: Conceptualization, Antecedents, and Multi-Level Consequences
}

\author{
Marie-Élène Roberge \\ Roosevelt University \\ Qiumei Jane Xu \\ Northeastern Illinois University \\ Anna Lisa Aydin \\ Goethe University Frankfurt \\ Wen-Rou Huang \\ National Chung Cheng University
}

\begin{abstract}
Creating an inclusive organizational climate is crucial to fully reach the full potential of diversity in organizations. Drawing on the optimal distinctiveness theory, we focus on the importance for an inclusive climate to optimally satisfy both, the need of belongingness and the need of uniqueness. We draw on the organizational climate literature and propose a conceptual model of an inclusive organizational climate. We contribute to the literature by refining the conceptualization of inclusive organizational climate, by examining five organizational antecedents (i.e., common in-group identity, weak faultlines, inclusive human resources policies and practices, functional communication, and inclusive leadership style), and by reviewing the literature on its potential multi-level consequences. Finally, the theoretical implications and practical applications of the proposed conceptual model are discussed.
\end{abstract}

Keywords: inclusive organizational climate, diversity management, identity, optimal distinctiveness theory

\section{INTRODUCTION}

Workplace diversity has increased on a global scale and has created both challenges and opportunities. Managing diversity effectively has become a priority in today's worldwide organizations to achieve positive performance outcomes such as leveraging creativity (Bodla, Tang, Jiang \& Tian, 2018) and innovation, increasing productivity (Miller, \& Triana, 2009), enhancing positive organizational culture and corporate image (Oswick \& Noon, 2014), reducing legal liability (Murphy, 2018), increasing shared market and customers' satisfaction (Hartel, \& Fujimoto, 2000; McKay, Avery, Liao, \& Morris, 2011), reducing turnover (Sacco \& Schmitt, 2005), and increasing employees' and organizational performance (Joshi, Liao, \& Jackson, 2006; McKay, Avery \& Morris, 2008, 2009). One of the most recommended managerial actions to reach such positive outcomes with a diverse workforce is to implement an inclusive climate that makes 
different people work effectively together. In an inclusive climate, "individuals of all backgrounds—not just members of historically powerful identity groups - are fairly treated, valued for who they are, and included in core decision making" (Nishii, 2013, p. 1754). We propose that an inclusive organizational climate is a key mediating factor that contributes to managing diversity successfully.

Diversity refers to differences among people (DiTomaso, 2021). It is a mixture of attributes within a workforce that in significant ways affect how people think, feel, and behave, as well as how they are accepted within the organization (Hays-Thomas \& Bendick, 2013). These diversity attributes may be visible or invisible, also referred in the literature as surface versus deep level diversity (Harrison, Price, Gavin \& Florey, 2002; Phillips, \& Loyd, 2006; Triana, Kim, Byun, Delgado \& Arthur, 2021). Surface level diversity referred to observable demographic characteristics such as gender, race, ethnicity, or age, whereas deep level diversity referred to non-observable characteristics such as education, socio-economic status, sexual orientation, religious beliefs, personality traits, personal values, and abilities/disabilities (for a review on workplace diversity see Roberson, 2019).

Research on diversity has found mixed results. On one hand, self-categorization theory and social identity theory (Reimer, Schmid, Hewstone, \& Ramiah, 2020; Tajfel \& Turner, 1986; Turner, Hogg, Oakes, Reicher, \& Wetherell, 1987) suggest that diversity often leads to negative outcomes because it encounters intergroup tensions due to the categorization process that classify people into an ingroup versus an outgroup (van Knippenberg, Nishii, \& Dwertmann, 2020). Research on diversity management has often examined the "problems" associated with diversity in organizations, such as prejudice, stereotyping, misunderstanding, interpersonal conflict, discrimination, remediating attendance, and retention issues (van Knippenberg \& Schippers, 2007; Williams \& O'Reilly, 1998). On the other hand, the literature has also focused on discovering ways to increase the overall organizational performance by reaching out for the full potential and advantages associated with diversity (Chatman, Polzer, Barsade, \& Neale, 1998; Foster \& Harris, 2005; Gozalez \& Denisi, 2009; Jehn, Northcraft, \& Neale, 1999; Jackson, \& Joshi, 2011; McKay, Avery, Tonidandel, Morris, Hernandez \& Hebl, 2007; Miller, \& Triana, 2009; Milliken \& Martins, 1996; Mor Barak, Cherin, \& Berkman, 1998; Nishii, 2013; Roberson, 2019; Wrench, 2005). Specifically, research suggests that diversity may lead to positive outcomes when it is implemented in an appropriate environment, where synergy exists among group members (van Knippenberg, Nishii, \& Dwertmann, 2020), meaning that there is a high level of integration of information among group members. Few studies have portrayed a complete picture of how such an appropriate environment is defined and conceptualized. Some researchers have focused on a diversity climate (Dwertmann, Nishii, \& van Knippenberg, 2016; Holmes, Jiang, Avery, McKay, \& Tillman, 2020), while others have examined an inclusive climate (Holvino, Ferdman, \& MerrillSands, 2004; Leroy, Buengler, Veestraeten, Shemla, However, 2021; Nishii, 2013; Pelled, Ledford, \& Mohrman, 2002; Shore, Cleveland, \& Sanchez, 2018; Shore, Randel, Chung, Dean, Ehrhart, \& Singh, 2011; Mor Barak, 2000; Mor Barak, Lizano, Kim, Duan, Rhee, Hsiao, \& Brimhall, 2016; Winters, 2014).

In this paper, we examine the research on an inclusive organizational climate. We contribute to the literature in three ways. First, we look at the existing theories and empirical studies to conceptualize an inclusive organizational climate. Second, we identify five organizational antecedents that contribute to create an inclusive organizational climate. And third, we review the literature and identify some multi-level consequences, predicted by an inclusive organizational climate.

\section{CONCEPTUALIZATION OF AN INCLUSIVE ORGANIZATIONAL CLIMATE}

An inclusive climate has recently been defined as "a collective perception that there are expectations and norms that allow employees to behave in a manner that is consistent with aspects of their self-concept together with the various identities that they hold, and that they are included in decision making and supported in sharing views that are not part of the status quo" (Shore et al. 2018, p. 181). This definition emphasizes that in an inclusive climate, different identities are valued, and the decision-making process is in support of sharing views that may differ from the traditional perspectives.

Nishii (2013) defined an inclusive climate by emphasizing three dimensions: 1) fair employment practices and diversity specific practices that help to eliminate bias; 2) integration of differences; and 3) 
inclusion in decision making. Another definition of an inclusive climate, proposed by Shore and colleagues (2011, pp. 1277), is that it is an environment "in which policies, procedures, and actions of organizational agents are consistent with fair treatment for all social groups, with a particular attention to groups that have had fewer opportunities historically and that they have been stigmatized in the societies in which they live." An inclusive climate has also been defined as workers' perception of a workplace atmosphere where everyone has a sense of belonging, is invited to participate in decisions, and feels that their input matters (Major, Davis, Sanchez-Hucles, Germano, \& Mann, 2006). Other researchers (Hayes, Bartle, \& Major, 2002) refer to it as a "climate for opportunity", defining it as "an individual overall perception of the fairness of the organization in terms of the management processes used to allocate opportunities, including interpersonal treatment and the distribution of opportunities in the organizational context (pp. 450)". Thus, an inclusive organizational climate provides a fair environment where equal access to employment and/or advancement is offered to all, which contributes to satisfy member's belongingness need. It can also allocate awards and recognition to value employees' unique work contribution, which will fulfill their need for uniqueness.

All these definitions of an inclusive climate are in support of optimal distinctiveness theory (Brewer, 1991, 2011; Leonardlli, Pickett, Brewer, 2010). This theory suggests that there are two main motivational factors (i.e., the belongingness need and the distinctiveness need) that must be optimally satisfied for group members to perceive being in an inclusive climate (Shore et al. 2011). Research drawing on optimal distinctiveness theory found that an inclusive climate must validate workers' identity by acknowledging their group memberships, while celebrating the uniqueness of everyone. For example, Shore and colleagues (2011) have conceptualized inclusion in a work group as satisfying both needs. Satisficing the need of belongingness may be achieved by valuing social identity groups that are meaningful and that may have been experiencing greater discrimination in the past (Bell, Özbilgin, Beauregard, \& Sürgevil, 2011; Roberson, 2006), while satisficing the need of uniqueness may be achieved by recognizing and valuing the distinctiveness of everyone's unique identity, and by making them feel welcome and accepted for who they are (Jansen, Otten, van der Zee, \& Jans, 2014; Shore, et al., 2011). It is in an inclusive climate that people connect with one another by sharing similarities and by shining for their differences. For example, an employee whose ethnicity is Hispanic may have knowledge about customers' preferences from sharing the same background. This knowledge is potentially valuable for the organization's success. If s/he is treated as an insider with distinct value, this Hispanic employee will have a strong sense of inclusion and the organization will be able to benefit through enhanced performance. In other words, in addition to emphasizing group membership, an inclusive climate emphasizes the valuable resources such as insights, knowledge, skills, abilities, values, perspectives, and experiences that people with various and unique identities bring to the organization (Ferdman, 2014; Nishii, 2013).

Thus, we define an inclusive climate at the organizational level. Drawing on optimal distinctiveness and on the organizational climate literature (Ostroff, Kinicki, \& Muhammad, 2013; Schneider \& Reichers, 1983; Schneider, Ehrhart \& Macey, 2011, 2013), we define an inclusive organizational climate as the employees' shared perception of the formal and informal organizational policies, practices, procedures, and routines that optimally satisfy both needs, their belonging need and distinctive need within the organization. A strong inclusive organizational climate indicates that such shared perception is widely accepted among employees of an organization (Ostroff, Kinicki \& Muhammad, 2013). When the climate is strong, as opposed to a weak climate, there is an aggregate construct or a higher-order social structure that exists (Schneider et al., 2011, 2013). In other words, a strong inclusive organizational climate is reflected when organizational members collectively have their belonging need and the distinctive need met, which explains how an inclusive organizational climate may lead to positive multi-level performance outcomes. This collective perception can be influenced by organizational factors, also called antecedents, such as those discuss in the following section. 


\section{THE ORGANIZATIONAL ANTECEDENTS OF AN INCLUSIVE ORGANIZATIONAL CLIMATE}

We propose, as shown in Figure 1, five organizational antecedents that may contribute to the development of an inclusive organizational climate. These antecedents are: 1) experiencing a common ingroup identity, 2) weak faultlines, 3) inclusive human resource policies and practices, 4) functional communication, and 5) inclusive leadership style. We propose, based on optimal distinctiveness theory, that these factors may increase the likelihood for organizational members to optimally satisfy their belonging need and their need for individuality (Shore, et al., 2011). Although it is not an exhaustive list, our conceptual model highlights and discusses those antecedents that are considered mostly critical for the creation of an inclusive organizational climate. Our model may serve as guidelines to stimulate future research avenues and to support practitioners' managerial strategies that pursue the goal to lead diversity to success.

\section{FIGURE 1}

\section{A CONCEPTUAL MODEL OF AN INCLUSIVE ORGANIZATIONAL CLIMATE}

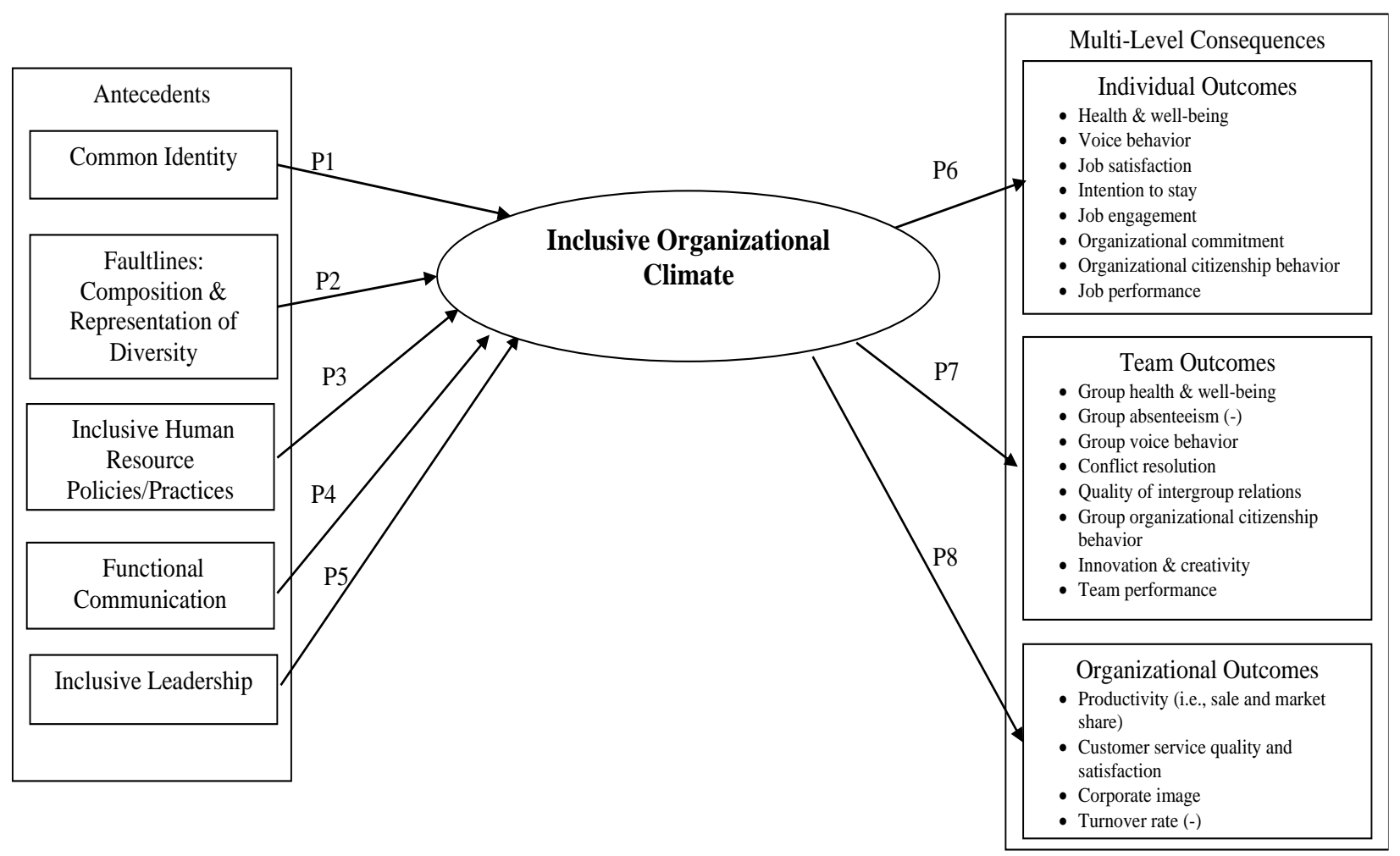

\section{A Common In-Group Identity}

Preliminary social psychology research on diversity and inclusion refers to the common in-group identity model (Gaertner, Dovidio, Anastasio, Bachman \& Rust, 1993; Gaertner, Dovidio, Guerra, Hehman, \& Saguy, 2016; Stamper, \& Masterson, 2002). This model suggests that sharing a common identity, such as sharing the same purpose, interests, goals, values and/or by being part of the same culture (Chatman, Polzer, Barsade, \& Neale, 1998) is considered a forerunner to enhance the likelihood of diverse groups to lead to positive performance outcomes. By creating a common ingroup in organization employers signal to their employees that such values are important to all members of the organization. A common ingroup can be developed via a strong organizational mission statement that focuses on diversity and inclusion. An example of such mission statement is the mission of Honda Corporation "The Power of Dreams" which 
states on its website that "We don't just encourage diversity, we build on it... Honda's values are grounded in human respect, and we stand with people everywhere united in the pursuit of racial equality and justice for all". Employees working in organizations with such mission statement may trust their company more easily and feel closer psychologically to one another, even those perceived different in the first place. For instance, experimental research shows how a common ingroup identity influences collective action for disadvantage members (Ufkes, Calcagno, Galsford \& Dovidio, 2016). Therefore, such result can be extended and applied to our model by suggesting that a common ingroup identity influences the creation of inclusive organizational climate, where members care for different others. Indeed, such psychological bond facilitates the creation of an inclusive organizational climate which will enhance the likelihood for diverse members to collaborate, and, in turn, to reach to positive performance outcomes (Dovidio, Gaertner, Ufkes, Saguy \& Pearson, 2016). Defining a superordinate identity provides diverse employees support to confirm their belonging need (Dovidio, Gaertner, \& Validzic, 1998). Thus, we propose:

Proposition 1: Sharing a common in-group identity positively influences the emergence of an inclusive organizational climate.

\section{Faultlines: Composition and Representation of Diversity}

Faultlines refer to the representation of diversity and the distribution of the diversity characteristics within the organization. Faultlines are described as the composition of the workforce on many different diversity attributes that may be visible or invisible. When different indicators of diversity converge (e.g., certain positions in an organization are predominantly filled by employees of a certain race and/or gender), the covariation of differences creates a diversity faultline that may elicit subgroup categorization (Lau \& Murnighan, 1998; 2005). Research suggests that the presence of faultlines negatively influence the creation of an inclusive organizational climate. For example, Lau and Murnighan (2005) found out that faultlines explained more variances in perceptions of team learning, psychological safety, satisfaction, and expected performance than single-attribute heterogeneity indexes. Moreover, the authors found that cross-subgroup work communications were effective for groups with weak faultlines but not for groups with strong faultlines.

Thus, research suggests that when there are strong faultlines, the diversity indicators create separation among organizational members which leads them to experience a lack of communication and identification among them (Luijters, Van der Zee, \& Otten, 2008), as well as a lack of identity confirmation (Milton, \& Westphal, 2005; Swann, Rentfrow, \& Guinn, 2005), which negatively impact the emergence of an inclusive organizational climate. In contrast, when the faultline is weak, there is coexistence of all types of diversity attributes among the group, leading members to perceive being in a fair environment in which diversity is well represented. Under weak faultline, an inclusive climate is more likely to emerge since people may perceive fairness and feel psychologically safe to express themselves among their organizational members, thus leading them to validate their identity and fulfill both needs (i.e., belonging need and distinctive need).

The more representation of diverse groups in organizations, the weaker the faultlines will be, and as a result more identity confirmation, less stereotypes prejudices and discriminatory behaviors will be displayed among organizational members, leading to the perception of a more inclusive organizational climate. However, when the faultlines are strong, people are divided by indicators of diversity (e.g. White female nurses, as opposed to Black male doctors) or when there is little diversity integration, such as when the representation of diversity in the organization mostly shows homogeneity among workers or a situation of tokenism (e.g., few minority members among many majority members), a poor inclusive organizational climate is likely to emerge. Thus, we propose:

Proposition 2: Faultlines in the organization negatively influence the emergence of an inclusive organizational climate. 


\section{Inclusive Human Resource Policies and Practices}

Researchers have widely recognized that effective diversity management can be achieved through the implementation of appropriate human resource policies and practices (Shen, Chanda, D'Netto \& Monga, 2009). Such HR policies and practices influence the emergence of an inclusive climate (Gelade, \& Ivery, 2003; Ostroff, \& Bowen, 2000; Rogg, Schmidt, Shull, \& Schmitt, 2001). Research suggests that when the organizational strategy and human resource policies and practices are inclusive, they support diversity related programs and initiatives, which in turn help to shape an inclusive climate (Kochan, et al., 2003; Roberge, Lewicki, Hietapelto, \& Abdyldaeva, 2011). For example, team building activities, mentoring programs, networking events, or diversity training programs are all diversity initiatives that may contribute to foster an inclusive organizational climate. Such HR initiatives offer a time for social interactions among group members, to get to know one another, and therefore to contribute to support the process of confirming each other's identities (Swann, Rentfrow \& Guinn, 2005). By confirming individuals' organizational memberships and individuals' distinctive identities, inclusive HR policies and practices can truly create an inclusive organizational climate which, in turn, brings forward successful collaboration efforts in between diverse members, leading to positive performance outcomes (Shore, et al, 2018).

There are a variety of inclusive human resource policies and practices, but all must be supportive of different group identities. For example, Button (2001) demonstrated that the more prevalent policies were intended to recognize and affirm gay and lesbian employees in the workforce (i.e., sexual diversity), the less likely sexual minority members were to experience treatment of discrimination. Further, when support to LGBTQ+ were provided, more equitable treatment was associated with higher levels of satisfaction and commitment among lesbian and gay employees as well as less bias (Belle, Özbilgin, Beauregards, \& Sürgevil, 2011; Bendl, Fleischmann, \& Hofmann, 2015; Gower, Forster, Gloppen, Johnson, Eisenberg, Connett, \& Borowsky, 2018). Thus, by increasing the identity confirmation process (Milton, \& Westphal, 2005) among organizational members which validates group membership and individuality, in this case sexual diversity, such type of policy contributes to the creation of an inclusive organizational climate.

Collins and Smith (2006) found that commitment-based human resource practices (i.e., selection, training and development, and compensation) affected social climates related to trust, cooperation, and shared information. Other research has shown that specific human resource practices, such as recruiting practices that are specifically identity conscientious, increase employees' perceptions of the organization being supportive of diversity (Highhouse, et al., 1999; Kim \& Gelfand; 2003).

Valuing diversity initiatives (Leslie, 2019) has become a popular managerial practice since a growing number of organizations have implemented policies and practices intended to value diversity in the workplace (Roberge et al., 2011). For example, the consideration of embracing diversity and inclusion as core business values and strategies has been implemented by recruiting, selecting, and integrating diverse people into the workplace, and by implementing affirmative action programs, as well as diversity training programs for businesses and governmental organizations (Naff \& Kellough, 2003; Roberson, Kulik, \& Pepper, 2003). In particular, the implementation of diversity training programs is also an opportunity to inform employees about policies and practices related to prohibiting discrimination in all forms, including bullying and sexual harassment in organizations. Such policies and practices are likely to influence the emergence of an inclusive climate in diverse organizations, which enhances the likelihood of reaching out to positive performance outcomes.

Implementing fair policies and practices also required knowing about individual differences and especially about individuals' needs to satisfy them. Implementing fair policies and practices requires a certain level of standardization, but at the same time it requires flexibility. For example, to embrace diversity and respond to it appropriately, organizations must offer reasonable accommodations to working parents (Shinn, Wong, Simlo, \& Ortiz-Torres, 1989), people living with disabilities (Roberge, Haq Abbasy, Huang, \& Lavoie, 2020; Steinberg, Iezzoni, Conill, \& Stineman, 2002) or people practicing different religions (Cash, \& Gray, 2000). Establishing idiosyncratic deals in diverse organizations has become an appropriate practice to enhance fairness perceptions and fulfilling organizational members' unique needs. Idiosyncratic deals are personalized employment arrangements negotiated between individual workers and employers, and intended to benefit both parties (Rousseau, 2005). By implementing such deals, the organization may 
offer flexible working hours, childcare provision, mentoring programs, or prayer time at work. Organizations that offer such practices show a higher commitment to the creation of an inclusive organizational climate. Thus, we propose:

Proposition 3: Inclusive human resource policies and practices positively influence the creation of an inclusive organizational climate.

\section{Functional Communication}

To achieve the emergence of an inclusive organizational climate, the literature suggests that organizations should value a functional communication flow that supports integration of information which enhances cooperation among group members (van Knippenberg, Nishii, \& Dwertmann, 2020). As proposed by information elaboration perspective (Roberge \& van Dick, 2010), effective communication is an important mechanism that explains how diversity may positively influence performance outcomes. When the communication among group members is effective, it becomes easier for them to confirm each other's identity on both needs (belonging need and distinctive need), as suggested by optimal distinctiveness theory. Similarly, as pointed out by the personalization model proposed in the literature about diversity management (Ensari \& Miller, 2006), when the context allows organizational members to interact, socialize, and communicate well with one another, they can learn about each other's personal lives and identities, which leads to reduced categorization process and may eliminate stereotyping and biases. Indeed, as discussed by the categorization-elaboration model (van Knippenberg De Dreu \& Homan, 2004), there are intergroup biases that result from social categorization processes that may disrupt the informational exchange processes, critical to realizing the value in diversity (Roberson, 2019). It is why stimulating information sharing and information integration among diverse members is extremely important to positively influence the emergence of an inclusive organizational climate (Bodla, Tang, Jiang \& Tian, 2018; van Knippenberg, Nishii, \& Dwertmann, 2020). Promoting effective communication channels is essential for creating an inclusive climate in diverse organizations. On one hand, when social interaction is allowed in the workplace, employees are more likely to communicate leading them to identify with one another and to confirm each other's group membership. On the other hand, when communication is encouraged among group members it may influence the chance to not only discover similarities between themselves and others, but also to develop mutual understanding and appreciation of differences that increase the likelihood of confirming each other's uniqueness. As a result, effective communication influences the creation of an inclusive climate which, in turn predicts positive performance outcomes. Thus, we propose:

Proposition 4: Functional communication positively influences the creation of an inclusive organizational climate.

\section{Inclusive Leadership Style}

To foster an inclusive organizational climate, the role of leaders is imperative. Inclusive leaders have a deep commitment to educating workers about diversity and encouraging them to engage into the process of learning from each other's identities. It requires employees to place a high value on spending time and interacting with each other to explore similarities that make them belong to the same groups, and to elaborate on each other unique identities that once considered into their respective work increase the overall organizational effectiveness. The core value of inclusive leadership is about making group members feel comfortable with differences, while handling effectively conflicts, and bringing forward discussions about difficult identity issues that occur when employees learn from one another's identity, such as revealing at work its religious beliefs, or its sexual orientation, or disclosing mental health problems or family issues. In an inclusive organizational climate, leaders make people with different identities feel comfortable to freely express who they are without the fear of being judged or rejected.

Leaders must be a good representative of a diverse group to foster a climate of inclusion. Inclusive leadership style refers to leaders that are aware of diversity and understand it, not only in terms of demographic characteristics, but also in terms of managing various identities in the workplace. Inclusive 
leaders show competencies at resolving diversity issues and conflicts. They encourage the validation of workers' group membership and the expression of their individuality to an optimal level. Inclusive leaders found the true value in belonging by promoting a common in-group with common values and same purpose, while appreciating the variety of opinions, insights, and identities among different workers (Homan, Gundemir, Buengeler, \& van Kleef, 2020; Hollander, 2009). Researchers have emphasized the role that top management plays in reaching to positive outcomes by creating an inclusive climate (Chin, 2010; Schein, 2010; Shore \& Chung, 2021). For example, Nishii and Mayer (2009) conducted a study showing that in diverse groups, an inclusive leadership may reduce turnover. The value of diversity and equal employment opportunity enacted by the top management can heavily influence the diversity practices implemented in organizations to successfully manage diversity. Such value held by middle managers and direct supervisors, for example, influences the implementation of managerial practices that promote inclusion (Shore, et al., 2011, Randel, Galvin, Shore, Ehrhart, Chung, Dean \& Kedharnath, 2018). Implementing inclusive policies and practices of human resource management is not always an easy task, it requires strong beliefs and commitment to inclusiveness. In a recent study, Buengeler, Leroy, and De Stobbeleir (2018) described how leaders shape the impact of HR diversity practices on employee inclusion depending on their philosophy and values aligned with those practices. The authors argue that diversity practices do not necessarily lead to inclusion, but that it depends on how leaders implement these practices.

Inclusive leaders provide a fair treatment to all, especially when resolving diversity issues and conflicts. By demonstrating commitment toward eliminating all forms of discrimination throughout the organization, inclusive leaders facilitate the establishment of an inclusive organizational climate. Inclusive leaders communicate to organizational members that they are all respected, valued and appreciated for who they are, which contribute to satisfying workers' need of belongingness and need of uniqueness. Inclusive leaders display behaviors that are consistent with the group values, and they display empathic concerns for group members, creating a psychological feeling of acceptance and safety for diverse group members (Homan, Gundemir, Buengeler, \& van Kleef, 2020; Roberge, 2013). The support and commitment from inclusive leaders reside in offering learning opportunities that represent different viewpoints and engagement from different members which contribute to the emergence of an inclusive organizational climate. As pointed out by van Knippenberg and colleagues (2020) leaders need to guide the group members by encouraging them to exchange information, be active listener, learn from others' perspectives, and talk about how to integrate the multiple ideas. Finally, some recent research also suggests that inclusive leaders value spirituality at work (Gotsis \& Grimani, 2017). Stimulating workers' spirituality by offering a meditation room at work, for example, can influence the creation of an inclusive climate. Thus, we propose:

\section{Proposition 5: Inclusive leadership style positively influences the creation of an inclusive organizational climate.}

\section{MULTI-LEVEL CONSEQUENCES OF AN INCLUSIVE ORGANIZATIONAL CLIMATE}

When an inclusive organizational climate is created, people feel their needs of belongingness and uniqueness as being both optimally satisfied. They perceived been fairly treated, supported by the organization, and feel psychologically safe working for their organization (Frazier, Fainshmidt, Kling, Pezeshkan, \& Vracheva, 2017). Therefore, when employees feel comfortable, valued, and respected in their work environment, research suggests that it positively influences individual, group, and organizational behaviors. Social exchange theory (Blau, 1964) provides a theoretical base for making such predictions. As part of the mutual investment, feeling fairly treated and receiving support from their organization creates an obligation for employees to reciprocate with favorable attitudes, behaviors, and performance. Researchers have begun examining the effects of an inclusive organizational climate on individual, group, and organizational outcomes (Mor Barak, et al., 2016). While several research studies suggest that such climate is related to several individual outcomes (Shore, et al. 2018; Vohra, \& Chari, 2015), only a limited number of studies has investigated the effects of an inclusive climate on group and/or organizational outcomes. Given three close related constructs (i.e., organizational justice (Colquitt, Conlon, Wesson, 
Porter, Ng, 2001), organizational support (Rhoades, \& Eisenberger, 2002) and psychological safety (Frazier, Fainshmidt, Kling, Pezeshkan, \& Vracheva, 2017)), we conducted a review of the literature that emphasizes the potential for multilevel outcomes to occur, when predicted by an inclusive organizational climate. We also propose that the stronger the climate is, the more positive impact the climate will have on multi-level outcomes.

\section{Individual Outcomes}

Research suggests that an inclusive organizational climate, given that it is fully developed, may lead to several positive individual outcomes. First, prior empirical research shows that an inclusive climate can be beneficial for employee health and well-being (Ndjaboué, Brisson \& Vézina, 2012). Employees who perceive being fairly treated in an organization are less sick and in better health. Similarly, Moliner, Martinez-Tru, Peiro, Ramos, and Cropanzano (2005) found that justice climate was negatively related to burnout. Spell and Arnold (2007) found that the interactive effects of distributive and procedural justice climates significantly reduce individual feelings of both anxiety and depression (Mor Barak, Findler, \& Wind, 2003). Thus, these studies have suggested that inclusive climate might be related to the health and well-being of the organizational members.

An inclusive climate might also be associated with employees' voice. When employees were fairly treated, they were less likely to be silent and more likely to voice their identity with members of their workgroup and be committed to their profession (Tangirala \& Ramanujam, 2008). Further, feeling psychologically safe can lower the stress level among group members and increase voice behavior in organizations. Evidence also suggests that an inclusive climate is associated with job satisfaction and a reduction of the intention to leave. Mor Barak and Levin (2002) found that employees' sense of exclusion played a critical role in explaining the connection between lack of opportunities experienced by employees who were different from the corporate's mainstream and their job satisfaction and well-being. Similarly, in a study of social workers, Acquavita, Pittman, Gibbons, and Castellanous-Brown (2009) found that feeling included predicted job satisfaction. Moreover, Mor Barak, Levin, Nissly and Lane (2006) found that feeling excluded from the decision-making process was a predictor of the intention to leave.

Another important potential outcome of an inclusive climate is employee engagement (Volpone et al., 2012). In a psychologically safe environment, employees may feel encouraged to ask questions, share new thoughts, and challenge colleagues to have more innovative ideas. Without the perception of psychological safety, suggesting new practices and procedures would seem overly risky. Nembhard and Edmondson (2006) found that in health care teams, an inclusive climate that assures psychological safety predicted engagement in quality improvement work.

Finally, an inclusive climate may lead to a high level of organizational commitment, identification, and organizational citizenship behavior. Findler, Wind, and Mor Barak (2007) found supportive results showing a positive relationship between inclusion and organizational commitment. Similarly, research conducted by Cho and Mor Barak (2008) showed that perception of inclusion was positively associated with both organizational commitment and job performance. Other research also supported that perception of organizational justice predicts organizational citizenship behavior (Jafari \& Bidarian, 2012). Thus, we propose:

Proposition 6: An inclusive organizational climate is positively related to employees' health and wellbeing, employee voice behavior, employee engagement, job satisfaction, organizational commitment, intention to stay, organizational citizenship behavior, and job performance.

\section{Group Outcomes}

A climate that provides justice, support, and psychological safety to meet employees' needs for belongingness and uniqueness may also affect group-level outcomes. For example, Moliner and colleagues (2005) found that group-level justice perception predicted group-level feelings of burnout. Colquitt, Noe, and Jackson (2002) found that justice climate, at the group level, was associated with both team 
performance and team absenteeism and that its effects were moderated by climate strength, such that the relationships were more beneficial in stronger climates.

Furthermore, it was found that when employees feel psychologically safe, they were more willing to be involved in decision making and to provide ideas for new and improved ways of working. The perceived support by all team members reinforced such voice behavior. Frazier and Bowler (2015) found that a climate that encouraged employee voice predicted group voice behavior and group performance. Burningham and West (1995) examined teams in an oil company and found that team-level perceptions of psychological safety and support led to higher group innovativeness.

People who worked in an inclusive climate were more likely to experience a high level of social cohesion which means that there are strong relational bonds among group members (Gaffikin \& Morrissey, 2010). Building on that finding, we suggest that an inclusive climate can positively affect the quality of intergroup relations within the organization (between groups of different gender, ethnicity, etc.). Within an inclusive climate in diverse organizations, problems surface, tensions arise, and conflicts may be experienced among group members, however, because conflicts can be openly discussed and a dialogue between group members can take place, the conflicts can be resolved instead of being avoided. Indeed, working in an inclusive climate helps to attenuate the tensions and it encourages people to find a resolution by providing an environment where mutual respect is a core value and where all team members are open minded to resolve the issues. Thus, diverse group members with the perception of being working within an inclusive climate may experience conflicts but by being under such type of climate, they are in a better place to tackle those conflicts effectively. Another research conducted by Chen, Lam, Naumann, and Schaubroeck (2005) found that procedural justice climate predicted group citizenship behavior, which was defined as the discretionary behavior presented by one group to support other group members of the organization. Thus, in an inclusive climate, groups tend to experience higher quality of intergroup relations, and display more group citizenship behaviors (Ehrhart, 2004). Finally, some recent research has found supportive evidence about the mediating effect of a "team-focused inclusion" in between harvesting the benefits of diversity and team creativity (Leroy, Buengler, Veestraeten, Shemla, \& However, 2021). We therefore propose:

Proposition 7: An inclusive organizational climate is positively related to group outcomes such as group health, group voice behavior, quality of intergroup relations, conflict resolution, group citizenship behavior, group innovation, group creativity, group performance, and negatively related to group absenteeism.

\section{Organizational Outcomes}

Research has suggested that organizational climate has a significant impact on important business outcomes (Reichers \& Schneider, 1990; Schneider, Ehrhart, Mayer, Saltz, \& Niles-Jolly, 2005). An inclusive organizational climate fosters positive work attitudes, motivates employees to work harder and be more creative in accomplishing their tasks, which in turn increases the overall organizational performance (Ashforth \& Mael 1989). Gelade and Ivery's (2003) empirical study has shown that a favorable work climate was associated with higher business performance. Also, research on diversity climate has examined how an overall perception of a diversity climate influences organizational outcomes such as productivity, sales, corporate image, and customer satisfaction (Mackey et al., 2009). Such research may be helpful for studies on inclusive climate. For example, Mackey and colleagues' (2009) study suggested that a diversity climate predicts store sales performance. The greatest sales growth was found in stores where subordinates and managers perceived a highly diverse climate. In contrast, the lowest sales growth was found in stores in which both subordinates and managers reported less hospitable diversity climate. Moreover, employees shared perceptions of organizational support for diversity and other diversity management practices may spill over to customers' perception during service delivery, resulting in higher customer service quality and customer satisfaction (Hartel, \& Fujimoto, 2000; McKay et al., 2011). Finally, Chrobot-Mason and Aramovich (2013) found that when employees perceive equal access to opportunities and fair treatment, intent to turnover decreases. Thus, we propose: 
Proposition 8: An inclusive organizational climate is positively related to indicators of organizational performance, such as productivity (e.g., sale and market share)), customer service quality and satisfaction, corporate image, and negatively related to turnover rate.

Although there is only a small body of existing literature on outcomes resulting from an inclusive climate, the overall research suggests that the creation of such a climate has positive effects on individual, group, and organizational outcomes. When an inclusive climate is created, people feel their needs of belongingness and uniqueness are both optimally met. Thus, when individuals feel welcome, valued, and respected in their work environment, it positively influences not only their individual performance outcomes, but also the group level, and organizational level of performance outcomes.

\section{DISCUSSION}

While diversity management has mainly focused on supporting minority employees, inclusion literature has shifted attention to creating an environment in which everybody perceives being an organizational member and valued for their uniqueness (Mor Barak, et al., 1998; Nishii, 2013; Shore et al., 2011; Shore, et al., 2018). This paper sheds light on a conceptual model of an inclusive organizational climate to provide guidance for future research avenues, to suggest the development of new theories about inclusive climate and diversity (Avery, 2020; Holmes IV, Jiang, Avery, McKay, Oh, \& Tillman, 2020; Nkomo, Bell, Roberts, Joshi, \& Thatcher, 2019) as well as to advise and help managers and practitioners to manage diversity effectively.

First, this paper elaborates on the concept of inclusive organizational climate by incorporating optimal distinctiveness theory and organizational climate literature. Belongingness and uniqueness needs are emphasized. Widely shared perception of meeting both needs among the employees is the core of an inclusive organizational climate. When organizational members collectively believe that their belonging need and distinctive need are met, an inclusive organizational climate emerges. With the clarification of the conceptualization and the level of analysis, it paves the way to measure the concept of inclusive organizational climate in future research (for a recent measure of group inclusion see Chung, Ehrhart, Shore, Randel, Dean \& Kedharnath, 2020). Second, the paper addressed potential organizational antecedents related to the creation of an inclusive organizational climate, such as sharing a common ingroup identity, experiencing weak faultlines, providing inclusive human resource policies and organizational practices, functional communication, as well as an inclusive leadership style. Future conceptual and empirical research could potentially examine other types of antecedents to better understand how to shape shared perceptions as being accepted and treated as an insider by others. Antecedents such as the organizational culture, whether is it a collective culture, as opposed to an individualism one (Avery, 2020) should be considered by future research. Such research ideas could be fruitful to continue improving our understand of how the social context influence the creation of such a climate. Also, research could examine other antecedents such as the organization's strategy, mission statement, and its core values. To shed light on a few more antecedents, researchers could also investigate individual level of antecedents such as employees' openness to diversity, and their engagement in learning organizations. Such types of antecedents may play an important role in predicting an inclusive organizational climate and could be added to the proposed model.

Third, an inclusive climate is conceptualized as being a multiple levels construct. It can be measured at an individual, group, and organizational level. Therefore, this suggests that there might be cross level linkages in between the inclusive climate and its antecedents and consequences (Rousseau, 2000). More research is needed in this area of the literature. In addition, this paper highlighted multi-levels consequences (i.e., individual outcomes, group outcomes, and organizational outcomes of an inclusive organizational climate). Prior research mainly focused on either the individual or group level outcomes. Only a few studies have examined the organizational level of consequences (Chen, Liu \& Portnoy, 2012; Gonzalez \& DeNisi, 2009; McKay et al., 2008). Understanding the multi-level consequences can be fruitful avenues for future 
research. It is critical to situate an inclusive climate within a broader organizational context by measuring several outcomes at different levels of analyses to better understand its overall effects.

Our model of inclusive organizational climate needs to be tested empirically. Studying the organizational antecedents and outcomes would be both theoretically and practically meaningful. Given the wide usage of the term "inclusive climate" among organizational practitioners, scholars need to continue to work on conceptual clarity by empirically validating the concept and testing the propositions. The strong building of the knowledge will effectively inform organizational leaders and members to be able to develop policies and apply practices that help to shape an inclusive organizational climate.

Furthermore, our model should be examined from a global perspective. Research on inclusive organizational climate shall consider the role of national and cultural context in which a diversity organization is located when shaping such climate (Shore, et al, 2018). This consideration of creating an inclusive organizational climate under a particular setting is critical to advance this literature. Also, multinational organizations may be cautious in sharing inclusive policies and practices developed in their home country with the host country in which the need for belongingness and uniqueness may vary. Global research that may increase our understanding and help successful application of management and leadership practices to shape an inclusive organizational climate is well needed.

\section{CONCLUSION}

Overall, this paper proposed and described a conceptual model of an inclusive organizational climate to guide future research avenues. Obviously, more field studies should be conducted to test the entire theoretical model in organizations. Organizational and longitudinal studies should be the next step for researchers to verify whether the model holds in organizational contexts. Moreover, from a practical standpoint, the model can be extremely helpful to establish a more complete diagnosis for problems arising in a diverse workforce. Considering the model of an inclusive climate and applying it to measure it, its antecedents, and consequences, it will provide relevant information as to what is going on in organizations related to diversity management. Moreover, by focusing on the proposed antecedents, it may help to facilitate the creation of an inclusive organizational climate, which will lead to positive outcomes at the individual, group, and organization levels.

\section{REFERENCES}

Acquavita, S.P., Pittman, J., Gibbons, M., \& Castellanous-Brown, K. (2009). Personal and organizational diversity factors' impact on social workers' job satisfaction: Results from a national Internetbased survey. Administration in Social Work, 33, 151-166.

Ashforth, B.E., \& Mael, F. (1989). Social identity theory and the organization. Academy of Management Review, 14, 20-39.

Avery, D.R. (2020). Lessons from the losing: Implications of the COVID-19 pandemic for organizational diversity scholarship and practices. Journal of Management Studies, 57(8), 1746-1749.

Bacharach, S.B., Bamberger, P.A., \& Bashdi, D. (2005). Diversity and homophily at work: Supportive relations among White and African-American peers. Academy of Management Journal, 48, 619644.

Belle, M.P., Özbilgin, M.F., Beauregards, T.A., \& Sürgevil, O. (2011). Voice, silence, and diversity in 21 st century organizations: Strategies for inclusion of gay, lesbian, bisexual, and transgender employees. Human Resource Management, 50, 131-146.

Bendl, R., Fleischmann, A., \& Hofmann, R. (2009). Queer theory and diversity management: Reading codes of conduct from a queer perspective. Journal of Management and Organization, 15(5), 625-638.

Blau, P. (1964). Power and Exchange in Social Life. New York: Wiley. 
Bodla, A.A., Tang, N., Jiang, W., \& Tian, L. (2018). Diversity and creativity in cross-national teams: The role of team knowledge sharing and inclusive. Journal of Management \& Organization, 24(5), 711-729.

Brewer, M.B. (1991). The social self: On being the same and different at the same time. Personality and Social Psychology Bulletin, 17, 475-482.

Brewer, M.B. (2011). Optimal distinctiveness theory: Its history and development. Handbook of Theories of Social Psychology, (2), 81-98.

Buengeler, C., Leroy, H., \& De Stobbeleir, K. (2018). How leaders shape the impact of HR's diversity practices on employee inclusion. Human Resource Management Review, 28(3), 289-303.

Burningham, C., \& West, M.A. (1995). Individual, climate, and group interaction processes as predictors of work team innovation. Small Group Research, 26, 106-117.

Button, S.B. (2001). Organizational efforts to affirm sexual diversity: A cross-level examination. Journal of Applied Psychology, 86, 17-28.

Cash, K.C., \& Gray, G.R. (2000). A framework for accommodating religion and spirituality in the workplace. Academy of Management Executive, 14, 124-134.

Chatman, J., Polzer, J., Barsade, S., \& Neale, M. (1998). Being different yet feeling similar: The influence of demographic composition and organizational culture on work processes and outcomes. Administrative Science Quarterly, 43, 749-780.

Chen, X-P., Lam, S.S.K., Naumann, S.E., \& Schaubroeck, J. (2005). Group citizenship behaviour: Conceptualization and preliminary tests of its antecedents and consequences. Group and Organization Review, 1, 273-300.

Chen, X-P., Liu, D., \& Portnoy, R. (2012). A Multilevel investigation of motivational cultural intelligence, organizational diversity climate, and cultural sales: Evidence from U.S. real estate firms. Journal of Applied Psychology, 97, 93-106.

Chin, J.L. (2010). Introduction to the special issue on diversity and leadership. American Psychologist, 65(3), 150-156.

Cho, S., \& Mor Barak, M.E. (2008). Understanding of diversity and inclusion in a perceived homogeneous culture: A study of organizational commitment and job performance among Korean employees. Administration in Social Work, 32, 100-126.

Chrobot-Mason, D., \& Aramovich, N.P. (2013). The psychological benefits of creating an affirming climate for workplace diversity. Group \& Organization Management, 38(6), 659-689.

Chung, B.G., Ehrhart, K.H., Shore, L.M., Randel, A.E, Dean, M.A., \& Kedharnath, U. (2020). Work group inclusion: Test of a scale and model. Group \& Organization Management, 45(1), 75-102.

Collins, C.J., \& Smith, K.G. (2006). Knowledge exchange and combination: The role of human resource practices in the performance of high technology firms. Academy of Management Journal, 49, 544-560.

Colquitt, J.A., Conlon, D.E., Wesson, M.J., Porter, C.O.L.H., \& Ng, K.Y. (2001). Justice at the millennium: A meta-analytic review of 25 years of organizational justice. Journal of Applied Psychology, 86, 425-445.

Colquitt, J.A., Noe, R.A., \& Jackson, C.L. (2002). Justice In Teams: Antecedents and Consequences of Procedural Justice Climate. Personnel Psychology, 55(1), 83-109.

Cox, T.H., Jr. (1994). Cultural diversity in organizations: Theory, research, \& practice. San Francisco: Berrett-Koehler.

DiTomaso, N. (2021). Why difference makes a difference: Diversity, inequality, and institutionalization. Journal of Management Studies. https://doi.org/10.1111/joms. 12690

Dovidio, J.F., Gaertner, S.L., \& Validzic, A. (1998). Intergroup bias: Status, differentiation, and a common in-group identity. Journal of Personality and Social Psychology, 75, 109-120.

Dovidio, J.F., Gaertner, S.L., Ufkes, E.G., Saguy, T., \& Pearson, A.R. (2016). Included but invisible? Subtle bias, common identity and the darker side of "we". Social Issues and Policy Review, 10(1), $6-46$. 
Dwertmann, D.J.G., Nishii, L.H., \& van Knippenberg, D. (2016). Disentangling the fairness \& discrimination and synergy perspectives on diversity climate: Moving the field forward. Journal of Management, 42, 1136-1168.

Ehrhart, M.G. (2004). Leadership and procedural justice climate as antecedents of unit-level organizational citizenship behavior. Personnel Psychology, 57, 61-94.

Ely, R.J., \& Thomas, D.A. (2001). Cultural diversity: The effects of diversity perspectives on work group processes and outcomes. Administrative Science Quarterly, 46, 229-273.

Ensari, N.K., \& Miller, N. (2006). The application of the personalization model in diversity management. Group Processes and Intergroup Relations, 9, 589-607.

Ferdman, B.M. (2014). The practices of inclusion in diverse organizations. In B.M. Ferdman \& B.R. Deane (Eds.), Diversity at work: The practices of inclusion (pp. 3-54). San Francisco, CA: Jossey-Bass.

Findler, L., Wind, L.H., \& Mor Barak, M.E. (2007). The challenge of workforce management in a global society: Modeling the relationship between diversity, inclusion, organizational culture, and employee well-being, job satisfaction, and organizational commitment. Administration in Social Work, 31, 63-94.

Foster, C., \& Harris, L. (2005). Easy to say, difficult to do: Diversity management in retail. Human Resource Management Journal, 15(3), 4-17.

Frazier, M.L., \& Bowler, Wm. M. (2015). Voice climate, supervisor undermining, and work outcomes: A group-level examination. Journal of Management, 41, 841-863.

Frazier, M.L., Fainshmidt, S., Kling, R.L., Pezeshkan, A., \& Vracheva, V. (2017). Psychological safety: A meta-analytic review and extension. Personnel Psychology, 70, 113-165.

Gaertner, S.L., Dovidio, J.F., Anastasio, P.A., Bachman, B.A., \& Rust, M.C. (1993). The common ingroup identity model: Recategorization and the reduction of intergroup bias. European Review of Social Psychology, 4(1), 1-26.

Gaertner, S.L., Dovidio, J.F., Guerra, R., Hehman, E., \& Saguy, T. (2016). A common ingroup identity: Categorization, identity, and intergroup relations. In T.D. Nelson (Ed.), Handbook of prejudice, stereotyping, and discrimination (pp. 433-454). Psychology Press.

Gaffikin, F., \& Morrissey, M. (2010). Community cohesion and social inclusion: Unravelling a complex relationship. Urban Studies, 48, 1089-1118.

Gelade, G.A., \& Ivery, M. (2003). The impact of human resource management and work climate on organizational performance. Personnel Psychology, 56, 383-404.

Gelfand, M.J., Nishii, L.H., Raver, J., \& Schneider, B. (2005). Discrimination in organizations: An organizational level systems perspective. In R. Dipboye \& A. Colella (Eds.), Discrimination at work: The psychological and organizational bases (pp. 89-116), Mahwah, NJ: Erlbaum.

Gonzalez, J.A., \& Denisi, A.S. (2009). Cross-level effects of demography and diversity climate on organizational attachment and firm effectiveness. Journal of Organizational Behavior, 30, 21-40.

Gotsis, G., \& Grimani, K. (2017). The role of spiritual leadership in fostering inclusive workplaces. Personnel Review, 46(5), 908-935. https://doi.org/10.1108/PR-11-2015-0286

Gower, A.L., Forster, M., Gloppen, K., Johnson, A.Z., Eisenberg, M.E., Connett, J.E., \& Borowsky, I.W. (2018). School practices to foster LGBT-supportive climate: Associations with adolescent bullying involvement. Prevention Science, 19, 813-821.

Harrison, D.A., Price, K.H., Gavin, J.H., \& Florey, A.T. (2002). Time, teams, and task performance: Changing effects of surface- and deep-level diversity on group functioning. Academy of Management Journal, 45(5), 1029-1045.

Hartel, C.E., \& Fujimoto, Y. (2000). Diversity is not the problem to be managed by organizations but openness to perceived dissimilarity is. Journal of Australian and New Zealand Academy of Management, 6(1), 14-27.

Hayes, B.C., Bartle, S.A., \& Major, D.A. (2002). Climate for opportunity: A conceptual model. Human Resource Management Review, 12, 445-468. 
Hays-Thomas, R., \& Bendick, M. (2013). Professionalizing diversity and inclusion practice: Should voluntary standards be the chicken or the egg? Industrial and Organizational Psychology, 6, 193205.

Highhouse, S., Stierwalt, S.L., Bachiochi, P., Elder, A.E., \& Fisher, G. (1999). Effects of advertised human resource management practices on attraction of African American applicants. Personnel Psychology, 52, 425-442.

Hollander, E.P. (2009). Inclusive leadership: The essential leader-follower relationship. New York, NY: Routledge.

Holmes, O., IV, Jiang, K., Avery, D.R., McKay, P., Oh, I., \& Tillman, C.J. (2020). A meta-analysis integrating 25 years of diversity climate research. Journal of Management, pp. 1-26. DOI:10.1177/0149206320934547

Holvino, E.H., Ferdman, B.M., \& Merrill-Sands, D. (2004). Creating and sustaining diversity and inclusion in organizations: Strategies and approaches. In M.S. Stockdale \& F.J. Cosby (Eds.), The psychology and management of workplace diversity (pp. 245-276). Malden, MA: Blackwell.

Homan, A.C., Gundemir, S., Buengeler, C., \& van Kleef, G.A. (2020). Leading diversity: Toward a theory of functional leadership in diverse teams. Journal of Applied Psychology, 105(10), 11011128.

Honda. (2021). The Power of Dreams. Retrieved from https://csr.honda.com/diversity/

Jackson, S.E., \& Joshi, A. (2011). Work team diversity. In S. Zedeck (Ed.), APA handbook of industrial and organizational psychology (pp. 651-686). Washington, DC: American Psychological Association.

Jafari, P., \& Bidarian, S. (2012). The relationship between organizational justice and organizational citizenship behavior. Social and Behavioral Sciences, 47, 1815-1820.

James, L.R., \& Jones, A.P. (1974). Organizational climate: A review of theory and research. Psychological Bulletin, 81(12), 1096-1112.

Jansen, W.S., Otten, S., van der Zee, K.I., \& Jans, L. (2014). Inclusion: Conceptualization and measurement. European Journal of Social Psychology, 44, 370-385.

Janssens, M., \& Zanoni, P. (2007). What makes an organization inclusive? Work contexts and diversity management practices favoring ethnic minorities' inclusion. Paper presented at the meeting of the Academy of Management, Philadelphia, PA.

Jehn, K., Northcraft, G., \& Neale, M. (1999). Why differences make a difference: A field study of diversity, conflict, and performance in workgroups. Administrative Science Quarterly, 44(4), 741-763.

Joshi, A., Liao, H., \& Jackson, S.E. (2006). Cross-level effects of workplace diversity on sales performance and pay. Academy of Management Journal, 49, 459-481.

Kim, S.S., \& Gelfand, M.J. (2003). The influence of ethnic identity on perceptions of organizational recruitment. Journal of Vocational Behavior, 63, 396-416.

Kochan, T., Bezrukova, K., Ely, R., Jackson, S., Joshi, A., Jehn, K., . . Thomas, D. (2003). The effects of diversity on business performance. Report of the diversity research network. Human Resource Management, 42, 3-21.

Kossek, E.E., Markel, K.S., \& McHugh, P.P. (2003). Increasing diversity as an HRM change strategy. Journal of Organizational Change Management, 16(3), 328-352.

Kozlowski, S.W.J., \& Klein, K.J. (2000). A multilevel approach to theory and research in organizations: Contextual, temporal, and emergent processes. In K.J. Klein \& S.W.J. Kozlowski (Eds.), Multilevel theory, research, and methods in organizations: Foundations, extensions, and new directions (pp. 3-90). Jossey-Bass.

Lau, D.C., \& Murnighan, J.K. (1998). Demographic diversity and faultlines: The compositional dynamics of organizational groups. Academy of Management Review, 23(2), 325-340.

Lau, D.C., \& Murnighan, J.K. (2005). Interactions within groups and subgroups: The effects of demographic faultlines. Academy of Management, 48(4), 645-659. 
Leonardelli, G.J., Pickett, C., \& Brewer, M.B. (2010). Optimal distinctiveness theory: A framework for social identity, social cognition, and intergroup relations. Advances in Experimental Social Psychology, 43, 63-113.

Leroy, H., Buengler, C., Veestraeten, M., Shemla, M., \& However, I. (2021). Fostering team creativity through team-derived inclusion: The role of leader harvesting the benefits of diversity and cultivating value-in-diversity beliefs. Group and Organization Management. Advance online publication.

Leslie, L.M. (2019). Diversity initiative effectiveness: A typological theory of unintended consequences. Academy of Management Review, 44(3), 538-563.

Li, C.R., Lin, C.J., Tien, Y.H., \& Chen, C.M. (2017). A multilevel model of team cultural diversity and creativity: The role of climate for inclusion. Journal of Creative Behavior, 51, 163-179.

Luijters, K., Van der Zee, K., \& Otten, S. (2008). Cultural diversity in organizations: Enhancing identification by valuing differences. International Journal of Intercultural Relations, 32(2), 154163.

Major, D.A., Davis, D.D., Sanchez-Hucles, J.V., Germano, L.M., \& Mann, J. (2006). IT workplace climate for opportunity and inclusion. Encyclopedia of Gender and Information Technology, p.7. DOI: $10.4018 / 978-1-59140-815-4 . c h 134$

McKay, P.F., \& Avery, D.R. (2015). Diversity climate in organizations: Current wisdom and domains of uncertainty. In M.R. Buckley, A.R. Wheeler, \& J.R.B. Halbesleben (Eds.), Research in Personnel and Human Resources Management (Vol. 33, pp. 191-233). Bingley, UK: Emerald Group Publishing Limited.

McKay, P.F., Avery, D.R., \& Morris, M.A. (2008). Mean racial-ethnic differences in employee sales performance: The moderating role of diversity climate. Personnel Psychology, 61, 349-374.

McKay, P.F., Avery, D.R., \& Morris, M.A. (2009). A tale of two climates: Diversity climate from subordinates' managers' perspectives and their role in store unit sales performance. Personnel Psychology, 62, 767-791.

McKay, P.F., Avery, D.R., Liao, H., \& Morris, M.A. (2011). Does diversity climate lead to customer satisfaction? It depends on the service climate and business unit demography. Organization Science, 22, 788-803.

McKay, P.F., Avery, D.R., Tonidandel, S., Morris, M.A., Hernandez, M., \& Hebl, M.R. (2007). Racial differences in employee retention: Are diversity climate perceptions the key? Personnel Psychology, 60, 35-62.

Miller, T., \& Triana, M.D.C. (2009). Demographic Diversity in the Boardroom: Mediators of the board diversity-firm performance relationship. Journal of Management Studies, 46(5), 755-786.

Milliken, F., \& Martins, L. (1996). Searching for common threads: Understanding the multiple effects of diversity in organizational groups. Academy of Management Review, 21, 402-433.

Milton, L.P., \& Westphal, J.D. (2005). Identity confirmation networks and cooperation in groups. Academy of Management Journal, 48, 191-212.

Moliner, C., Martinez-Tur, V., Peiro, J.M., Ramos, J., \& Cropanzano, R. (2005). Relationships between organizational justice and burnout at the work-unit level. International Journal of Stress Management, 12, 99-116.

Mor Barak, M., Findler, L., \& Wind, L. (2003). Cross-cultural aspects of diversity and well-being in the workplace: An international perspective. Journal of Social Work Research and Evaluation, 4, 4973.

Mor Barak, M.E. (2000). The inclusive workplace: An ecosystems approach to diversity management. Social Work, 45, 339-352.

Mor Barak, M.E., \& Levin, A. (2002). Outside of the corporate mainstream and excluded from the work community: A study of diversity, job satisfaction, and well-being. Journal of Community, Work and Family, 5, 133-157. 
Mor Barak, M.E., Cherin, D.A., \& Berkman, S. (1998). Organizational and personal dimension in diversity climate: Ethnic and gender differences in employee perceptions. Journal of Applied Behavioral Science, 34, 82-104.

Mor Barak, M.E., Levin, A., Nissly, J.A., \& Lane, C.J. (2006). Why do they leave? Modeling child welfare workers' turnover intentions. Children and Youth Services Review, 28, 548-577.

Mor Barak, M.E., Lizano, E.L., Kim, A., Duan, L., Rhee, M., Hsiao, H., \& Brimhall, K. (2016). The promise of diversity Management for climate of inclusion: A State-of-the-Art review and metaAnalysis. Human Service Organizations: Management, Leadership \& Governance. DOI: $10.1080 / 23303131.2016 .1138915$

Morgeson, F.P., \& Hofmann, D.A. (1999). The structure and function of collective constructs: Implications for multilevel research and theory development. Academy of Management Review, 24(2), 249-265.

Murphy, W. (2018). Distinguishing diversity from inclusion in the workplace: Legal necessity or common sense conclusion? The Journal of Business Diversity, 18, 65-83.

Naff, K., \& Kellough, E. (2003). Ensuring employment equity: Are federal diversity programs making a difference? International Journal of Public Administration, 26, 1307-1336.

Ndjaboué, R., Brisson, C., \& Vézina, M. (2012). Organizational justice and mental health: A systematic review of prospective studies. Occupational Environment Medical, 69, 694-700.

Nembhard, I.M., \& Edmondson, A.C. (2006) Making it safe: The effects of leader inclusiveness and professional status on psychological safety and improvement efforts in health care teams. Journal of Organizational Behaviour, 27, 941-966.

Nishii, L.H. (2013). The benefits of climate for inclusion for gender-diverse groups. Academy of Management Journal, 56(6), 1754-1774.

Nishii, L.H., \& Mayer, D.M. (2009). Do inclusive leaders help to reduce turnover in diverse group? The moderating role of leader-member exchange in the diversity to turnover relationship. Journal of Applied Psychology, 94, 1412-1426.

Nkomo, S.M., Bell, M.P., Roberts, L.M., Joshi, A., \& Thatcher, S.M.B. (2019). Diversity at a critical juncture: New theories for a complex phenomenon. Academy of Management Review, 44(3), 498517.

Ostroff, C., \& Bowen, D.E. (2000). Moving HR to a higher level. In K.J. Klein \& S.W.J. Kozlowski (Eds.). Multilevel Theory, Research, and Methods in Organizations (pp. 211-265). San Francisco, CA: Jossey-Bass Wiley.

Ostroff, C., Kinicki, A., \& Muhammad, R. (2013). Organizational culture and climate. In N. Schmitt (Ed.), Handbook of Psychology, 12. Wiley \& Sons.

Oswick, C., \& Noon, M. (2014). Discourses of diversity, equality and inclusion: Trenchant formulations or transient fashions? British Journal of Management, 25, 23-39.

Pelled, L.H., Ledford, G.E., Jr., \& Mohrman, S.A. (2002). Demographic dissimilarity and workplace inclusion. Journal of Management Studies, 36(7), 1013-1031.

Phillips, K.W., \& Loyd, D.L. (2006). When surface and deep-level diversity collide: The effects on dissenting group members. Organizational Behavior and Human Decision Processes, 99, 143160.

Randel, A.E., Galvin, B.M., Shore, L.M., Ehrhart, K.H., Chung, B.G., Dean, M.A., \& Kedharnath, U. (2018). Inclusive leadership: Realizing positive outcomes through belongingness and being valued for uniqueness. Human Resource Management Review, 28, 190-203.

Reichers, A.E., \& Schneider, B. (1990). Climate and culture: An evolution of constructs. In B. Schneider (Ed.), Organizational climate and culture (pp. 5-39). San Francisco: Jossey Bass.

Reimer, N.K., Schmid, K., Hewstone, M., \& Al Ramiah, A. (2020). Self-categorization and social identification: Making sense of us and them. In D. Chadee (Ed.), Theories in social psychology (2nd ed.). Wiley-Blackwell.

Rhoades, L., \& Eisenberger, R. (2002). Perceived organizational support: A review of the literature. Journal of Applied Psychology, 87(4), 698-714. 
Rhoades, L., \& Eisenberger, R. (2002). Perceived organizational support: A review of the literature. Journal of Applied Psychology, 87, 698-714.

Roberge, M.É. (2013). A Multi-Level Conceptualization of Affective Empathy to Explain How Diversity Increases Group Performance. International Journal of Business and Management, 8(3), 122133.

Roberge, M.É., Haq Abbasy, M.R.U., Huang, W.R., \& Lavoie, S. (2020). Mental health in organizations. American Journal of Management, 20(4), 10-20.

Roberge, M-É., Lewicki, R.J., Hietapelto, A., \& Abdyldaeva, A. (2011). Theory to practices: Recommending supportive diversity practices. Journal of Diversity Management, 6, 1-20.

Roberge, M.É., \& Van Dick, R. (2010). Recognizing the benefits of diversity: When and how does diversity increase group performance. Human Resource Management Review, 20, 295-308.

Roberson, L., Kulik, C.T., \& Pepper, M.B. (2003). Using needs assessment to resolve controversies in diversity training design. Group \& Organization Management, 28, 148-174.

Roberson, Q.M. (2006). Disentangling the meaning of diversity and inclusion in organizations. Group \& Organization Management, 31, 212-236.

Roberson, Q.M. (2019). Diversity in the workplace: A review, synthesis, and future research agenda. Annual Review of Industrial and Organizational Psychology and Organizational Behavior, 6, 6988.

Rogg, K.L., Schmidt, D.B., Shull, C., \& Schmitt, N. (2001). Human resource practices, organizational climate, and customer satisfaction. Journal of Management, 27, 431-449.

Rousseau, D.M. (2000). Multilevel competencies and missing linkages. In K.J. Klein \& S.W.J. Kozlowski (Eds.), Multilevel theory, research, and methods in organizations: Foundations, extensions, and new directions (pp. 572-582). Jossey-Bass.

Rousseau, D.M. (2005). I-deals: Idiosyncratic deals employees bargain for themselves. New York: M. E. Sharpe.

Sacco, J.M., \& Schmitt, N. (2005). A dynamic multilevel model of demographic diversity and misfit effects. Journal of Applied Psychology, 90, 203-231.

Schein, E.H. (2010). Organizational culture and leadership. San Francisco, CA: Jossey-Bass.

Schneider, B. (1987). The people make the place. Personnel Psychology, 40, 437-454.

Schneider, B., \& Reichers, A.E. (1983). On etiology of climates. Personnel Psychology, 36, 19-37.

Schneider, B., Ehrhart, M.G., \& Macey, W.A. (2011). Perspectives on organizational climate and culture. In S. Zedeck (Ed.), Handbook of industrial and organizational psychology (pp. 373-414). Washington, DC: American Psychological Association.

Schneider, B., Ehrhart, M.G., \& Macey, W.H. (2013). Organizational climate and culture. Annual Review of Psychology, 64, 361-388.

Schneider, B., Ehrhart, M.G., Mayer, D.M., Saltz, J.L., \& Niles-Jolly, K. (2005). Understanding organization-customer link in service settings. Academy of Management Journal, 48, 1017-1032.

Shen, J., Chanda, A., D’Netto, B., \& Monga, M. (2009). Managing diversity through human resource management: An international perspective and conceptual framework. The International Journal of Human Resource Management, 20, 235-251.

Shinn, M., Wong, N.W., Simko, P.A., \& Ortiz-Torres, B. (1989). Promoting the well-being of working parents: Coping, social support, and flexibility job schedule. American Journal of Community Psychology, 17, 31-55.

Shore, L.M., \& Chung, B.G. (2021). Inclusive Leadership: How leaders sustain or discourage work group inclusion. Group \& Organization Management, 1059601121999580.

Shore, L.M., Cleveland, J.N., \& Sanchez, D. (2018). Inclusive workplaces: A review and model. Human Resource Management Review, 28, 176-189.

Shore, L.M., Randel, A.E., Chung, B.G., Dean, M.A., Ehrhart, K.H., \& Singh, G. (2011). Inclusion and diversity in work groups: A review and model for future research. Journal of Management, 37, $1262-1289$. 
Shrotryia, V.K., \& Dhanda, U. (2019, January-March 2019). Content validity of assessment instrument for employee engagement. SAGE Open, pp. 1-7.

Spell, C.S., \& Arnold, T.J. (2007). A multi-level analysis of organizational justice climate, structure, and employee mental health. Journal of Management, 33(5), 724-751.

Stamper, C.L., \& Masterson, S.S. (2002). Insider or outsider? How employee perceptions of insider status affect their work behavior. Journal of Organizational Behavior, 23, 875-894.

Steinberg, A.G., Iezzoni, L.I., Conill, A.C., \& Stineman, M. (2002). Reasonable accommodations for medical faculty with disabilities. Journal of American Medical Association, 228(24), 3147-3154. doi:10.1001/jama.288/24/3147

Swann, W.B., Jr., Rentfrow, P.J., \& Guinn, J.S. (2005). Self-verification: The search for coherence. In M.R. Leary \& J.P. Tangney (Eds.), Handbook of Self and Identity (pp. 367-383). New York: Guilford.

Tajfel, H., \& Turner, J.C. (1986). The social identity theory of intergroup behavior. In S. Worchel \& G. Austin (Eds.), Psychology of intergroup relations (pp. 7-24). Chicago: Nelson.

Tangirala, S., \& Ramanujam, R. (2008). Employee silence on critical work issues: The cross level effects of procedural justice climate. Personnel Psychology, 61, 37-68.

Triana, M.C., Kim, K., Byun, S.Y., Delgado D.M., \& Arthur, W., Jr. (2021). The relationship between team dee-level diversity and team performance: A meta-analysis of the main effect, moderator, and mediating mechanisms. Journal of Management Studies, pp. 1-43. doi: 10.1111/joms. 12670

Turner, J.C., Hogg, M.A., Oakes, P.J., Reicher, S.D., \& Wetherell, M.S. (Eds.). (1987). Rediscovering the social group: A self-categorization theory. Oxford: Blackwell.

Ufkes, E.G., Calcagno, J., Galsford, D.E., \& Dovidio, J.F. (2016). Understanding how common ingroup identity undermines collective action. Journal of Experimental Social Psychology, 63, 26-35.

van Knippenberg, D., \& Schippers, M.C. (2007). Work group diversity. Annual Review of Psychology, $58,515-541$.

van Knippenberg, D., De Dreu, C.K.W., \& Homan, A.C. (2004). Work group diversity and group performance: An integrative model and research agenda. Journal of Apply Psychology, 89, 100822.

van Knippenberg, D., Nishii, L.H., \& Dwertmann, D.J.G. (2020). Synergy from diversity: Managing team diversity to enhance performance. Behavioral Science and Policy, 6(1), 75-92.

Vohra, N., \& Chari, V. (2015). Inclusive workplaces: Lessons from theory and practice. The Journal for Decision Makers, 40(3), 324-362.

Volpone, S.D., Avery,D.R., \& McKay, P.F. (2012). Linkages between racio ethnicity, appraisal reactions, and employee engagement. Journal of Applied Social Psychology, 42(1), 252-270.

Williams, K.Y., \& O'Reilly, C.A., III. (1998). Demography and Diversity in Organizations: A Review of 40 years of research. Research in Organizational Behavior, 20, 77-140.

Winters, M.F. (2014). From diversity to inclusion: An inclusion equation. In B.M. Ferdman \& B.R. Deane (Eds.), Diversity at work: The practices of inclusion (pp. 205-228). San Francisco, CA: Jossey-Bass. 